\title{
EARLY MEDIGAL EDUCATION IN ENGLAND IN RELATION TO THE PRE-HISTORY OF LONDON UNIVERSITY
}

by

\author{
CHARLES SINGER and S. W. F. HOLLOWAY
}

THE foundation of the medical school and hospital that now bears the name of University College and, at first, that of the University of London, came at a turning-point in the social and intellectual history of medicine in general and of medical education in England in particular. Such a change cannot be understood without considering the circumstances in which it arose. To do this we must look beyond the event itself and indeed beyond England itself. Modern medical education in England has had a very different history from that of any other country, different even from that of Scotland and Ireland. With the opening of the University of London in 1828 the character of English medical education began slowly to change but to this day it bears many traces of the old order.

In all other western countries, including Scotland and Ireland, higher medical education has been for many centuries closely associated with universities. In England, and in England only, medical teaching was not intimately related to the universities. Until well after the middle of the nineteenth century, medical education in England was concentrated overwhelmingly in London where there was no university until 1828 and no university hospital till 1834 .

Scientific medical teaching in Europe is traceable ultimately to the northern Italian universities. There, some trace of it can be followed back to the Middle Ages, notably at Bologna and Padua. Certain of the Italian medical schools maintained a very high reputation until the end of the eighteenth century and even later. The greatest of the early medical professors at the University of London, William Sharpey (1802-80) found his early inspiration at Pavia, though it is often erroneously given as Padua.

In France, as in Italy, medical teaching reached a first post-medieval peak about the middle of the sixteenth century. Paris has ever since been much visited by foreign medical men. Almost all the early professors of the medical faculty of London University had some experience of the teaching at Paris. Contacts were naturally interrupted during the Napoleonic wars, but with their end in 1815 Paris became again a resort for English students. Thus J. R. Bennett (c. I 798-183I), who taught anatomy at London University from 1828 till his early death, studied and taught from 1822 to 1828 in Paris. He found there some two hundred British medical students-all or nearly all holding 
medical degrees or diplomas-and for them he conducted a special anatomy class.

Leyden, through its offspring in Edinburgh, is also linked with London University, though in a less direct way than Paris. With the establishment, at the end of the sixteenth century, of the independence of the States-General (predecessor of the Dutch Republic in the Low Countries), science, literature and the arts-and not least the science, literature and art of medicine-came to flourish at Leyden and especially at the university which was then founded in that city. By the end of the seventeenth century, under the greatest of modern physicians, Hermann Boerhaave ( $\left.1665^{-1} 73^{8}\right)$, the University of Leyden rose to a place second to none among the medical centres of the world. English, Scottish and Irish students, especially of medicine, flocked there. Throughout the eighteenth century, they found there better medical and scientific teaching than could be met elsewhere, and none was excluded for race, colour, nationality or religion. So far as Britain is concerned, it was through the University of Edinburgh that Boerhaave and Leyden had their profoundest influence.

At Edinburgh University, early in the eighteenth century, the practice arose of associating systematic instruction at the bedside with the teaching of the basic sciences in adjoining buildings. This method was introduced there in 1720 by Alexander Monro primus (1697-1767), a devoted pupil of Boerhaave and Leyden. The method soon spread to Glasgow. The London medical schools received a large part of their educational tradition from Edinburgh and Glasgow. Alexander Monro the first-there were three of them in direct descent-in his long teaching career at Edinburgh he is said to have had no fewer than 14,000 pupils. Nearly all of the first generation of professors of the medical and scientific subjects at the University of London, and many of later generations, had degrees from Edinburgh, Glasgow or Dublin.

But the Edinburgh and Leyden influence was evident much earlier. Indeed most of the great medical teachers in England during the eighteenth and first half of the nineteenth centuries had learned their art at Edinburgh and many had also studied at Leyden or Paris or both. All this while the magnificently endowed medical schools at Oxford and Cambridge remained wrapt in slumber. Besides anatomy, Edinburgh established, during the eighteenth century, departments of chemistry, botany, pathology and physiology. (The last was there known as 'the Institutes of Medicine'.) Both academic and extra-mural departments were active at Edinburgh. Glasgow, Dublin and Aberdeen developed medical teaching on the same model.

In England the medical departments at Oxford and Cambridge were merely nominal until after the middle of the nineteenth century though many great discoverers, from William Harvey ( $1578-1650)$ onward, and many great clinicians, from Thomas Sydenham (1624-89) onward, received their literary training at these ancient seats of learning. Until the Royal Institution in 1800 and the University of London in 1828 broke the tradition, there were, south 


\section{Early Medical Education in England}

of the Tweed, hardly any effective professors of the general sciences and none of the medical sciences. Scientific investigation remained a voluntary task, an exercise of leisure hours of busy surgeons and physicians and of the less busy hours of amateurs, but always entirely unpaid. There were certainly some professors of medical or para-medical subjects at the ancient universities, but few or none of them added or, perhaps, sought to add to knowledge. And even Thomas Campbell (1777-1844), the reputed father of the idea of the University of London, unguardedly committed himself, as late as 1825, to the view that authorship might be a disqualification for the holder of a chair and that research was hardly a part of the duty of a university teacher.

We can give no figures for the general training of those who practised medicine in England as a whole at the opening of the nineteenth century. It happens, however, that in 1805 a reliable and experienced physician, Dr. Edward Harrison ( $1766-1838$ ), made a careful investigation of all the practitioners in the county of Lincolnshire. He found 90 per cent without a shadow of proper training. Lincoln was and is an agricultural county, with no large towns. Doubtless industrial areas and the great cities had a better equipped medical personnel. It is, however, most unlikely that, until the first two decades of the nineteenth century were passed, more than half of those attending the sick in the country as a whole had had more medical education than apprenticeship to apothecaries or surgeons. Nevertheless it was just during this period that the 'general practitioner' was beginning to acquire a more definite status.

The direction of medical studies in England was determined, early in the nineteenth century, almost entirely by two professional bodies, the Royal College of Surgeons and the Society of Apothecaries. Emerging from the 'Surgeons' Company' the Royal College of Surgeons became effective in 1800, as an examining and licensing body. Membership of the College was conferred by an hour's oral examination by its self-elected 'Court' of aged and often fatigued men who formed its governing body. The Society of Apothecaries became entitled, by an Act of Parliament of 1815 , to a monopoly in England and Wales of licensing 'apothecaries'.

Licences from these two bodies, if held by the same man, became the best available warrants for the class of those whom we would now call 'general practitioners', a description which seems to have been first used in the eighteentwenties. These formed then, as they form still, the overwhelming majority of those who attend the sick. We cannot, however, give any statistical statement on the medical profession for another fifty years though we do know that in that period medical reform had effected great changes.

It is perhaps as well to say something here of the use of the terms 'apothecary' and 'surgeon' in the early nineteenth century. Operations on the cavities of the body, except 'cutting for stone', were rare and seldom undertaken except in hospitals or by hospital surgeons. Of major operations the commonest were amputations of a limb with a crude death-rate of some 15 per cent, and the most notorious 'cutting for stone' with a crude death-rate of at least 20 per cent. But 


\section{Charles Singer and S. W. F. Holloway}

the title 'surgeon' as applied to the ordinary family medical attendant did not suggest these heroic procedures but rather that its bearer was more expert with external diseases than with internal. The best qualified family medical men were both Members of the Royal College of Surgeons and Licentiates of the Society of Apothecaries. The term 'general practitioner' was in common use by 1860 . By then a series of Acts of Parliament had made respectable practice difficult for the completely unqualified man.

In the Medical Directory of 1856 , names of the old unqualified practitioners, which were admitted only if in practice before 1815 , have almost disappeared. The names in 1856 can be divided into eight classes as follows:

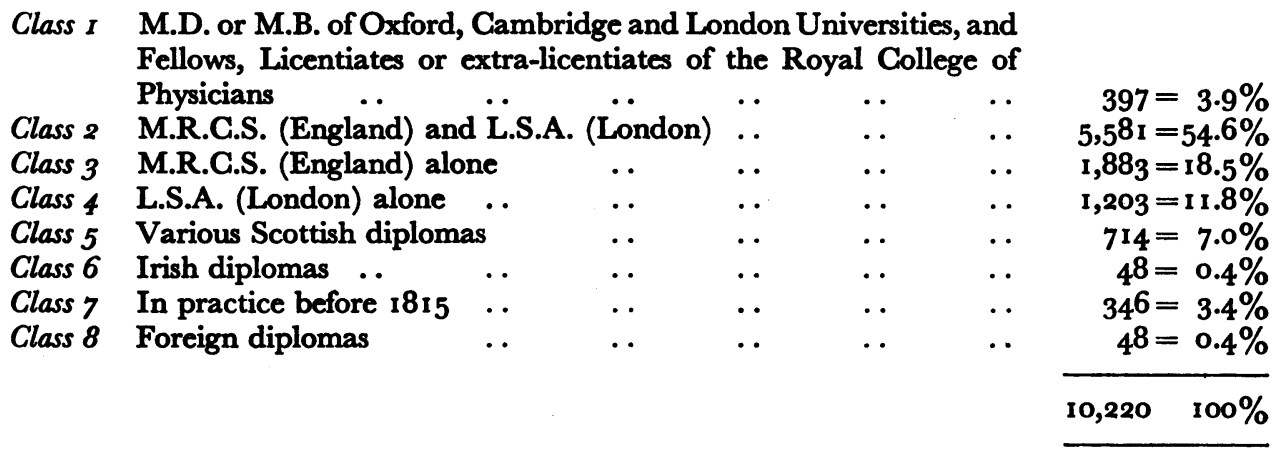

Unfortunately the early numbers of neither the unofficial Medical Directory (first published, but for the London area only, in 1845) nor the official Medical Register (first published in 1859), yield very exact pictures of the state of medical practice. They are least reliable for rural areas. Anyone could practise on any patient who, knowing his want of status, would permit him to do so. (For that matter he can do so to this day.) Licensure is a guarantee of training and it was, of course, always an offence for any to represent himself as having had training that he had not received. Nor, in the mid-nineteenth century, could any person without certain recognized diplomas, sue for a fee for giving advice, for prescribing drugs, for operating, or for other treatment. But many unqualified quacks, and many better disposed bone-setters, ladies-bountiful, wise-women, herbalists, and many others were treating the sick, especially in rural areas, until far beyond the mid-century.

Apart from errors due to mere human fallibility in both Register and Directory, there were reasons that make early numbers of these works unreliable. The reformers and the profession generally were much disappointed with the Medical Act of 1858 when it became clear that they were unable to prosecute quacks while the Council itself developed no clear policy and was timid and hesitant in its action. Moreover, the unreasonable fee of $£ 5$ was charged for registration. Some reputable practitioners saw no good reason for paying this. A good example is Joseph Maclise, F.R.C.S. (1810?-89), a pupil and demonstrator 


\section{Early Medical Education in England}

at University College, a surgeon of repute and the anatomical artist of Richard Quain. Maclise never registered. As for the Directory it could only give, then as now, what the medical man cared to send it.

Moreover until about I86o apprenticeship-which may be another name for more or less supervised practice by unqualified men-was still normal. 'Covering', that is employing an unqualified assistant as though he were qualified, persisted till the present century. It is an offence that probably still occasionally recurs. But the status of the medical man was steadily rising largely under the influence, both direct and indirect, of the University of London which took material form in 1828 .

In the late eighteenth and early nineteenth centuries effective clinical teaching was available in London in only four great teaching centres, 'Barts', the 'United Borough Hospitals' (i.e. St. Thomas's and Guy's, then almost adjoining but separated in 1825), St. George's, and the London. These were the most regularly 'walked' by students. All these hospitals had distinguished members on their staffs but the promotion to staff rank was seldom impartial. Those who stressed this most-among them Thomas Wakley (1 795-1862), the able, energetic, useful and expertly abusive founder of The Lancet-were not always themselves the most impartial.

Benjamin Golding (1793-1863) in his Historical Account of St. Thomas's Hospital (1819) describes-doubtless not without some personal feeling but also doubtless truly-how the honorary staffs of many London hospitals were elected. In the less respectable, bribery in various forms was, he says, quite normal. Voting at elections of the staff was the privilege of the governors. Often the appointments could be indirectly purchased and this statement can be documented. The method was simple. It involved no passage of coin from palm to palm. A candidate could himself create new governors by paying their admission fees. Thus he who could bear the most expense was most likely to be elected. After all the money was spent on relieving the sick poor! 'Charity shall cover the multitude of sins.'

At the more respectable hospitals, says Golding:

the governors consult the 'principal resident officer' [the Treasurer], who is better able to decide the competency of the candidates by noticing their conduct whilst acquiring their professional knowledge. . . Every person who offers himself to a respectable hospital is supposed to have received his education at that hospital, and to be well acquainted with everything of importance belonging to it. On this account, it is customary in appointing a surgeon, to select him from amongst those who have attended the hospital as apprentice, under the management and instruction of the former surgeons.

The rival claims of inbreeding and outbreeding in medical schools echo down the ages. They may even be heard, by the attentive ear, in the history of University College Hospital and Medical School.

Though nominally 'honorary', the clinical appointments in the teaching hospitals were valuable not only for the scientific and clinical opportunities that they gave but also for two material reasons. Firstly, and especially in the 


\section{Charles Singer and S. W. F. Holloway}

early nineteenth century, the 'honorary' surgeon or physician obtained fees from his apprentices, that is from his students or housemen. Secondly, these, when later in practice, were likely to call their old chief in consultation. Thus through the eighteenth and nineteenth centuries and indeed until the National Health Act of 1948, an 'honorary' appointment in a teaching hospital, by a curious inversion of the lexical meaning of the word, became of far more financial value than any available 'paid' post. To say this is by no means to deny that 'honorary' posts were also valued for the scientific opportunities that they offered. Nor is it to suggest that the overwhelming majority of 'honorary' teachers at medical schools were not high-minded and highly competent men, devoted to their subject and to the service of their patients.

Yet there is no doubt that appointments went too often to relations or apprentices, or assistants of those in office, in the early part of the century at least. For certain apprenticeships or dresserships or clerkships many hundreds of pounds were charged in the early nineteenth century. Five hundred pounds and even double that figure was not a very rare price. There are said to have been cases when dresserships were actually auctioned. It is also more than probable that some apprenticeship fees were paid with the tacit understanding that the assistant would succeed his chief. Yet, despite abuses, there were very able men on the staffs of all the teaching hospitals. For the earlier period it suffices to mention William Blizard (1772-1838) at the London, Astley Cooper ( $1763-1841$ ) at the United, John Abernethy ( $1764-1831$ ) at 'Barts', and, above all, John Hunter (1728-93) at George's. These and many such names remain among the ornaments of British medicine.

These four were all surgeons. The position and status of physicians was considerably different. To practise as a physician in London and the surrounding country it was necessary to receive the licensure of the Royal College of Physicians of London. This body had legal power to prevent others from practising as physicians in that area. Their licence was not granted to those in general practice, or likely to enter it, or to those who did not hold a university degree. Some degree of this kind could, however, be obtained by methods not very clearly distinguishable from purchase. The Fellows of the College formed a more select but self-elected group.

The Royal College of Physicians, it is true, rarely exercised its powers to prevent the practice of a physician's calling within the London region. The expensive nature of legal proceedings and the difficulty of securing a conviction were deterrents against prosecution.* Until 1834 the basic fact concerning the Fellowship of the Royal College of Physicians was, however, that only exceptionally could any person gain election to it unless he were a graduate of Oxford or Cambridge. Between 1771 and 1833 of the 149 Fellows admitted only nineteen had not graduated at one or another of these universities. And it was impossible for any to become a physician to a great hospital in London without the licence or fellowship of the College.

\footnotetext{
* To mulct an offender for infringing its rights, the College would need to prove that his practice was medical not surgical, and that he had practised daily for a month.
} 


\section{Early Medical Education in England}

But the greatest grievance against the College of Physicians in the first half of the nineteenth century was that, with all the prestige of its ancient standing, it did nothing for medical education, and that for long it obstructed moves for an adequate licensure of those who attended the sick, and specifically for the establishment of a teaching university. Until the middle of the century, the College of Physicians took no share even in examining candidates except in its own restricted field. Indeed it was not until $188_{4}$ that the physicians were finally able to agree with the surgeons to establish a 'conjoint examination' which soon became the normal entry into general practice in England.

Most physicians who were effective men of science, had little influence on the highly conservative committee of their own College. That body remained aloof till the eighties, content to stand on its dignity. Its main activity as a body was the performance of its own rites. Theoretically the physician directed the surgeon and apothecary and even the midwife in their tasks. This was a situation that could arise only with the wealthy to whom alone-hospital patients apart-the physician's services were commonly available. The purely clinical physician was tending to pass out of the realities of medical practice.

Nearly all eminent or successful physicians earned their reputations as officers of the great teaching hospitals, but a few of the greatest clinicians of the late eighteenth or early nineteenth centuries did not. The typical physician was a man of culture, learning and judgment. The most eminent clinician of the eighteenth century, William Heberden the elder (1710-1801), was all these things and, beyond doubt, a man of science as well. His works are consulted to this day. Yet he had no hospital appointment. George Birkbeck (I 776-184I), the eponymous founder of Birkbeck College, was in much the same case. A noteworthy proportion of successful physicians of the time were Quakers and, as such, were cut off from the old universities. Typical was J. C. Lettsom (1744-18I5), a product of Leyden, Edinburgh, and St. Thomas's. From his student days, he took careful notes of his cases, a rare practice at the time. He had many philanthropic, professional, literary, and scientific contacts but he held no teaching post.

By the mid-nineteenth century, in addition to certain provincial centres, there were active in London no less than eleven medical schools. All still survive. Each provided facilities for training in the clinical subjects, leading to licensure as a practitioner of medicine, and each maintained also instruction in some, at least, of the sciences ancillary to medicine. Each was based on a great hospital. The distinctive feature of University College Medical School and of its sister foundation attached to King's College was that they were specially equipped to teach the ancillary sciences for they employed full time professors of these subjects.

The beginnings of the systemization of the medical teaching in England, which led, in the nineteenth century, to the linkage of the scientific and clinical studies was so gradual that, for each of the earlier foundations, we can give only an approximate date. Moreover, the term 'teaching' must be 


\section{Charles Singer and S. W. F. Holloway}

considered under three headings, that of what we now regard as basic sciences, such as chemistry and physics, that of the ancillary sciences such as anatomy and physiology, and that in which these basic and ancillary sciences are combined with traditional and personal experience in the clinical art.

Nowadays these three categories are separated-perhaps too rigidly-and studied in the order given. But well into the nineteenth century training in preliminary, ancillary, and clinical matters proceeded more or less simultaneously. This is, or was till recently, the practice in France. There is perhaps something in its favour. In England, the general separation of the medical course into these three strata was advanced by the movement which produced the University of London. It became inevitable with advancing knowledge of the nature of infection and contagion.

Furthermore for all the eighteenth and at least the first half of the nineteenth century, the numerous 'private' medical schools were accessories-sometimes, from the student's point of view essential accessories-to the public hospital medical schools. A few of the many private schools were managed by men of great scientific distinction. All the anatomy schools and especially the private schools, necessarily had an unsavoury reputation in connection with the scandal of body-snatching which was rife until the passing of the Anatomy Act in 1832 .

Best known of the private schools was that in Great Windmill Street, close to what is now Piccadilly Circus. It had been opened in 1768 by the very distinguished Scot, William Hunter (1718-83), who was physician-accoucheur to the Middlesex Hospital. Another Scot, William Cruikshank (1745-180o), a skilled anatomist and experimenter, became his assistant in 1771 . In 1783 Cruikshank was joined by Matthew Baillie ( $1761-1823$ ), also a Scot, brotherin-law of John Hunter, later a physician to St. George's and the best morbid anatomist of his time in Britain. In 1805 Benjamin Brodie the elder ( $1782-1863$ ), later President of the Royal Society and of the Royal College of Surgeons, further added his talents to the school. It was bought in 1812 by yet another eminent Scot, Charles Bell, afterwards the first professor of surgery in the University. Brodie was elected to the staff of St. George's in 1822 and Bell to that of Middlesex in $182 \mathrm{I}$. Through Bell the Great Windmill Street school came into close relation with the Middlesex Hospital school into which most of its activities were absorbed. It thus gradually faded and, after several moves, was closed in 1843 .

A comparable fate overtook the other private schools. With the improvement of the schools attached to the hospitals, largely the result of the changes introduced at University College, the private schools gradually degenerated into cramming places for inferior students. One private school was, as we have seen, the ancestor of the school of Middlesex Hospital, another of that of St. Mary's. One private school was not closed until the death of its owner, Thomas Cooke, F.R.G.S., in I9or. It is interesting to recall that Cooke was a medical graduate of Paris.

The eleven public medical schools were attached to the following hospitals: 
(a) $\begin{cases}\text { I } & \text { Bartholomew's founded I123 } \\ 2 & \text { Thomas's founded in thirteenth century } \\ & \text { (School separated from Guy's in 1825) }\end{cases}$

(b) $\left\{\begin{array}{rlr}3 & \text { Westminster founded } & 1719 \\ 4 & \text { Guy's founded } & \text { (School separated from } \\ & \text { Thomas's in 1825) } \\ 5 & \text { George's founded } & 1734 \\ 6 & \text { London founded } & 1740 \\ 7 & \text { Middlesex founded } & 1745\end{array}\right.$

(c) $\left\{\begin{array}{rll}8 & \text { Charing Cross founded } & 1821 \\ 9 & \text { University College founded } & 1828 \\ \text { 10 } & \text { King's College founded } & 1836 \\ \text { 1 I } & \text { Mary's founded } & 1846\end{array}\right.$ organized teaching 1731 organized teaching $174^{\circ}$

organized teaching $184 \mathrm{I}$ organized teaching $174^{\circ}$

organized teaching 1752 organized teaching 1785 organized teaching 1822

organized teaching 1821 organized teaching 1828 organized teaching 1839 organized teaching $1854^{*}$

* Since 1874 there has been in London also a Medical School for Women attached to the Royal Free Hospital.

These hospitals fall naturally into three groups. The first $(a)$ are foundations surviving Henry VIII's seizure of monastic property. The next $(b)$ are products of eighteenth-century humanitarian movements. The third $(c)$ are nineteenthcentury institutions founded with teaching in view. The Westminster and the Middlesex Hospital differ from the other members of the second group in that, though founded in the eighteenth century, the definitive acceptance of teaching in their wards was delayed until the nineteenth century. The movement which led to this produced also the schools of University College, King's, and perhaps of Charing Cross.

We have hitherto spoken of the developments of medical teaching in early nineteenth-century London as though they formed a series or chain of events, each of which led naturally to the next. But those events took place in a complex social, political, scientific and philosophical setting which affected medicine, while medicine, in its turn, affected it. We cannot here disentangle all the strands in that backcloth but can indicate only a few of the more prominent.

By the early decades of the century, the Industrial Revolution had greatly increased the number of citizens in the middle income range. This class added both to the demand for and the supply of reasonably equipped practitioners. More could afford to pay for medical service, though seldom at the rate usual for physicians. Moreover, those of middle income could afford also to give their sons a long and expensive education, provided that this established them in life. It is a fair statement that, until the National Health Act, an overwhelming proportion of medical students came from a significantly narrow social group.

Furthermore, from the end of the eighteenth century, the Industrial Revolution was producing larger towns and some of these were fusing into conurbations. This movement concentrated the practices of doctors. A practitioner had now less ground to cover and he could thus visit more patients in less time and consequently at lower rates. He could thus gain more and better experience. Moreover, increase in the size of towns also encouraged, and indeed demanded, both the foundation of hospitals and their use for medical training. Before the nineteenth century had begun, the day had dawned of great provincial 
hospitals and these, one after the other, became places for apprenticeship and ultimately medical schools which have since become incorporated as faculties of universities.

The dominant philosophical influence in England of the first third of the century was that of Jeremy Bentham (1748-1832), and the dominant economic influence was still that of Adam Smith (1723-90) whose Wealth of Nations was first issued in 1776 . The doctrines of the utilitarians, of the philosophic radicals, and of the free-traders flowed naturally from the views of these thinkers. There was a general belief in 'progress' for generations before Darwin gave it his peculiar form. Ignorance, it was believed, was the fundamental trouble and education, it was considered, was the cure for that and most other ills. The theme could be developed that the foundation of the nineteenth-century medical schools of London was more or less the remote outcome of the utilitarian point of view that emanated from these schools of thought. This has been done more than once for University College. Nevertheless medicine is not a system either of moral or of natural philosophy, nor is it a mere response to economic needs. It is basically a humane way of aiding the sick and it has, in every age, among all peoples, used all the means within its reach-or believed to be within its reach-to attain that end. It has done this in the darkest as in the most enlightened centuries. Medicine is, in fact, no more than a special organized response to man's social instinct.

With the nineteenth century science was gaining in prestige. Thus it became the doctor's guide, his way of life, just as the brougham became his way of transport and the frock coat and top-hat his professional costume. Few medical men were conscious of forming members of any philosophic, economic or political movement. They were mostly ordinary, intelligent, kindly men seeking to make an honest, lucrative and interesting living by treating the sick and relieving suffering in ways that seemed best to their teachers and themselves.

We can, therefore, display the history of even a pioneer institution, such as the University of London in which scientific medicine was taught, without too extended a discussion of its philosophic basis, just as we can discuss mathematics without much debate on the nature of number, and chemistry without deep consideration of the reality of the external world. We can not only discuss these subjects as sciences; we can also apply them as arts. The change in medical teaching from the empiric to the scientific was made possible because ordinary people of moderate means and moderate intelligence began to suspect that their health was not being as well cared for as it might be. The public had the model of more effective teaching across the Channel and over the Border, and they had the plain warning of abuses nearer home. No level-headed man wished to be treated by incompetents or quacks. That was the common sense feeling that supported and still supports the medical schools.

The apothecaries were a fairly respected body whose services were at hand. Physicians were aloof, expensive and unwilling to visit as the patient willed. As for surgery, all men fear the knife and would like to be sure that it is in the safest and most conservative hands. It was an obvious step to make the 


\section{Early Medical Education in England}

apothecaries, through their most organized body, the Society of Apothecaries, the primary guardians of the public's health, at least in London. And it was the next obvious thing to do the same with the temperamentally more reluctant Royal College of Surgeons.

The 'apothecaries' of the time were of varied status and competence. Some merely sold drugs and cosmetics over the counter, some gave advice in the shop, some kept shops but called at the patients' homes, and some, keeping no shops, visited some patients and saw others in their consulting rooms, whilst supplying medicines only to their patients. These last, of the highest status among apothecaries, performed the functions of the now rare class of dispensing general medical practitioners.

The position of 'apothecaries' was both raised and regularized by the persistent and tactful efforts of George Man Burrows (I 77 I-1840), a member both of the Society of Apothecaries and of the Royal College of Surgeons. Burrows visualized more clearly than anyone else the proper status of those whom we now know as 'general practitioners'. He organized a body which he called the 'Association of Surgeon-Apothecaries' and, acting through this body, persuaded the Society of Apothecaries to promote a bill-passed in 1815 - that would give them licensure of medical practice throughout England and Wales, outside London and the surrounding area.

Legally, until that date, apothecaries could charge only for medicines but not for advice or treatment. This of course made it tolerably certain that very few consulted an apothecary without receiving a dose of some kind. Apothecaries of the highest class were, however, accustomed to receive from their more wealthy or generous patients gratuities added to their accounts. For them these gratuities became the main source of income.

A case of this bad practice is that of 'Old Q', the infamous fourth Duke of Queensbury (1724-1810), a notorious and very wealthy old rake and associate of the equally reprobate Prince Regent. In his later and infirm years he claimed the constant attendance - often for all the night and for weeks on end-of his apothecary who, he said, must be paid by his heirs. On his death this apothecary sent in a bill for $£ 16,000$. He had paid 9,250 visits to the Duke and had even slept at his house in Piccadilly on 1,215 nights and thus sacrificed much of his practice. The executors were sympathetic but, as some of the heirs were minors, they suggested a friendly legal action. In I8I I this apothecary was awarded $£ 7,500$ plus costs. Two sentences in the speech for the defence reveal the situation:

It is right that the apothecary should receive a remuneration, and we all know that he expects, ultra his charge for Medicines, whatever the liberality of the patient may induce him to give. If he is not properly paid for his first attendance, he will say the next time 'You must send for someone else.'

This notorious case advertised the inequitable nature of the system. If the executors had not given generous and straightforward evidence, the unfortunate apothecary would have recovered nothing, an evident injustice to one trained 
both by a long apprenticeship and as student at a renowned hospital. Public sympathy was turned to those of his calling.

In a relatively short period after the trial-short in view of the intolerable delay in this country that is still demanded for obviously needed legal reformsthe Society of Apothecaries brought to a successful conclusion the movement, skilfully steered by Burrows, for legal recognition as medical advisers of its licensed members. The Apothecaries' Act became law in 1815. It enacted that, by fulfilling certain conditions and by passing the examination of the Society, an apothecary could practise medicine and recover charges for his services. The era of the general practitioner, as we know him, had begun. The status of the general practitioner was further defined, or rather permitted to define itself, by a legal decision of 1830 that he might charge for attendance or medicine but not for both. This had the effect of separating the dispensing apothecary, or doctor as we now call him, from the dispensing druggist, chemist or pharmacist.

There was no further important legislation affecting the status of the general practitioner till the institution of the General Medical Council in 1858. The chief function of the medical schools of London from 1815 to 1858 was to train young men to be good doctors with the status given by the Licentiateship of the Society of Apothecaries or the Membership of the Royal College of Surgeons, or better, by both. To tell the history of University College Medical School in these terms would, however, be a perversion and contraction of its main activity and influence, for it was, from the first a centre of learning and research.

Linked with the question of the supply and equipment of general practitioners is that of the source of those who trained them and especially of the physicians and surgeons attached to the great teaching hospitals. It is a remarkable feature of English social history that a country so wealthy, so settled, so civilized, so industrially advanced, so humane and so liberal in its outlook, remained so long with but two universities and those completely out of touch with the spirit of the times, peculiarly unsympathetic to scientific development, and firmly set on perverting the meaning of the word 'humanities'. How could the country secure any supply of well trained, well educated and scientific medical teachers? And yet it did obtain them.

A partial explanation is that there was a number of graduates, highly trained in science and experienced in clinical medicine, continuously emerging from Edinburgh, Glasgow, and Dublin, many of whom had worked at Leyden, or Paris or Göttingen. These provided most of the best medical teachers in London. A second partial explanation is that, after the middle of the century, the place of a university training in medicine was, to some extent, taken by the higher diplomas, first of the Royal College of Surgeons and later also of the Royal College of Physicians. With the establishment of the youngest medical school in London (except that for women) that at St. Mary's in 1854, the metropolis had adequate accommodation for students (other than for women). The instruction of students gave occupation and, indirectly, emolument for highly trained scientific physicians and surgeons. Of course promotion of the teaching hospitals by no means exhausted the humanitarian energy of the age. A 


\section{Early Medical Education in England}

multitude of other hospitals and infirmaries, general and special, were founded in the London area throughout the century and these all needed staffing.

Despite these numerous hospitals, a weak point of medical education in London was that the student showed reluctance-not always discouraged by his teachers-to visit institutions other than his own school. This reluctance sometimes led to an illusion of shortage of clinical material. None except the most enterprising of the English students developed anything comparable to the Wanderjahr of the Germans.

Charing Cross Hospital, University College Hospital, King's College Hospital, and St. Mary's Hospital differ from other London teaching hospitals in that they were founded with their use for medical education definitely in view. In some degree all four are products of a rational movement of liberal reform which has long been recognized in more general social history and has culminated in the Welfare State.

University College medical school and hospital were among the chief early medical products in London of that great reform movement that swept Lord Grey into power. They were not, however, the only medical products. The more ancient medical schools were putting their houses in better order and the appointments to the medical faculty even of King's College-an Anglican foundation-were little hampered by religious bias. But it soon became apparent that the very idea of a University of London was a challenge to the ascendancy of the Tory party which, as it was then organized was based on Oxford and Cambridge. Robert Peel, the Tory leader, saw it as such and, as M.P. for Oxford and Home Secretary, wrote to the Dean of Christ Church, Oxford, in 1825 concerning the proposed foundation of London University:

This must be opposed and rejected, but I have hardly time to give to such an important project all the attention which it deserves. Can you tell me where I can look for that which it would be useful for me to know?

Brougham, on the other side, wrote to the wealthy radical, Sir Francis Burdett (1770-1844), who was for thirty years M.P. for Westminster and the champion of free speech, that the institution of the new university

is an event of infinite moment in my view which will do more to crush bigotry and intolerance than all the Bills either of us will ever see carried, at least until a Reform happens.

One London institution has usually been omitted, perhaps rather unjustly, from accounts of this movement. Charing Cross Hospital was designed from the first, in 1822, much as University College Hospital, both for clinical teaching and for scientific research. The matter never went much further than the design, but it was in some sort of operation as soon as University College Hospital. It owes its foundation to one man, Dr. Benjamin Golding (1 793-1863) who broached his idea publicly in 182I, and therefore earlier than Thomas Campbell. Soon after that he obtained control of a small local dispensary and funds for reconstructing it. His manifesto was wordy and his scheme far too ambitious for any support he had or for which he could hope. The subjects to be taught 
were to be chemistry, physics, botany, geology, anatomy-theoretical, practical, pathological and comparative-materia medica, dietetics, medical jurisprudence, theory and practice of medicine, surgery, midwifery, gynaecology, diseases of the eye, ear and teeth, 'anatomical machinery' (orthopaedics), tropical medicine, as well as naval and military surgery and mental diseases and their pathology. Despite having had several very distinguished teachers and pupils, nothing near that programme was ever reached at Charing Cross or perhaps at any other school. But Golding deserves some credit for the idea and the attempt to fulfil it.

The kind of students that the University medical school might hope to attract must be considered. In the making of such an estimate it is necessary to say something of what brought students to London. Till 1819-when the Apothecaries' Act of 1815 and the failure of their own Bill had stirred the College of Surgeons-there was no printed curriculum for the examination of either a surgeon or an apothecary. These examinations necessarily brought the student to London but the apprenticeship was still, and for long remained, the main thing in the course demanded by either licensing body.

Apprenticeship to a surgeon or apothecary could be taken anywhere. If there was a good hospital in the town in which the student lived-and in this respect no town was so well provided as London-then it was to his advantage to be attached to one of the surgeons or physicians, or sometimes, as at Exeter, to the apothecary, who served it. As much as $£ 500$ was on occasion paid for an apprenticeship to a surgeon at the Worcester Hospital, and comparable sums were paid at other provincial centres. This was much the price paid for apprenticeship to a good London surgeon. There was, however, no adequately organized school at most of these provincial towns and, as yet, little dissection at any of them. None of them could as yet give a licence and thus a serious student in order to practise had ultimately to get to London unless he was one of the few able to sustain a university course in Scotland or Ireland. In any event he had to visit London for his examination and the great majority found it necessary to make a longer stay. But costs of living were higher in London, and apprenticeship was in general more expensive there than in the provinces. Very high sums were sometimes paid in special cases for London apprenticeships and they may well have been good investments.

In 1813 the College of Surgeons made a rule that the candidates for its diploma should produce a certificate of a year's attendance on the surgical practice of a hospital. This was in addition to a certificate of a lecture course on anatomy and another on surgery. The hospitals in London at which attendance could be accepted were limited by the College in 1819 to Bartholomew's, the United (i.e. Thomas's and Guy's), Westminster, St. George's, the London, and the Middlesex. Certain hospitals in Edinburgh, Glasgow, Aberdeen, and Dublin were also accepted. This rule naturally led to protest from some of the great provincial hospitals where medical schools were beginning to form. In 1826 the College of Surgeons yielded to the extent that apprenticeship in a provincial hospital was accepted provided the student spent two years instead 


\section{Early Medical Education in England}

of the one demanded in London. In 1828 this was changed to one year at a London hospital or four years at a provincial plus six months at a London hospital. In 1829 this was altered again to one year at a provincial plus six months at a London hospital. These rapid changes were the result of unedifying discussion and not a little ill-feeling with which we are hardly concerned. The length of sojourn in London was the main bone of contention.

But the College of Surgeons was at war not only with the provincial schools but also with the private schools in the Metropolis itself. In 1822 it demanded 'attendance on three courses of anatomical lectures (with demonstrations) ... delivered in the winter session'. The operative word is winter because only then, by reason of difficulties in preservation, was dissection practised in the public schools. But methods of preservation were at this time steadily improving, and the private schools were perhaps more skilled in the art of preservation. At any rate they were prepared to dissect all the year round and their very existence depended on this. In 1826 a further attempt to limit the all-the-year-round activity of the private schools was made by extending the demand to three winter courses of lectures on anatomy and one winter course of lectures on what was, in effect, operative surgery on the dead body.

The Apothecaries Act of 1815 required that candidates for the licensure of the Society (which then became effectively compulsory for practitioners who dispensed) should have attended two courses of lectures in medicine and two in anatomy and physiology. The Act almost compelled certain provincial centres to start such lectures. The Society spent much time 'recognizing' these places. The College of Surgeons, as we have seen, adopted the opposite policy and tended rather to force students to work in London.

From what has been said the reader will rightly infer that the history of medical education in London in the early nineteenth century is not all a record of disinterested men seeking only the public good. Several champions of invective were involved in the discussion, for which perhaps mélée would be the more correct word. To include choicer specimens of their oratory would add to the readability of these pages, but it is perhaps better to risk dullness than to convert them into a manual of vituperation.

The champion athlete of medical vituperation was undoubtedly Thomas Wakley (1 795-1861), the able and public spirited editor of The Lancet which he founded in 1823 . Wakley certainly did much to reform the teaching and practice of medicine. He ardently advocated what he regarded as pure democracy. This form of government, however, was never allowed to disturb the peace which doubtless always reigned within the office of The Lancet. The founders of the University of London were also advocates of what most of them held to be pure democracy. Nevertheless there was a difference, from man to man, as to the essential nature of such purity. Wakely sometimes took a poor view of the University varieties of purity and this occasionally led him to send forth with the numbers of his journal certain denunciatory missives which did little to ease the growing pains of the university.

It will be well here to glance briefly at the comparative status of medicine 


\section{Charles Singer and S. W. F. Holloway}

in London as against that in Paris. England was so great a power in the early nineteenth century, her people were so conscious of having saved Europe from the last catastrophe of unification, their trade and industry was so rapidly advancing, they were so convinced of the stability and reasonableness of their own form of government-that is to say those who governed were thus convinced -and, above all, they were so forward in the technical arts that they failed to realize how backward the country was in science and especially in the sciences related to medicine. To say this is not to ignore the greatness of some English men of science of the time. It is true that Thomas Young (1 773-1829) had rung out the old and rung in the new in the first days of the century with his wavetheory of light. He, Humphry Davy ( $1778-1829)$ and W. H. Wollaston ( $1766-1828)$ and not a few gifted or fortunate amateurs were soon publishing the results of many researches. But the obstinate fact remained that there was only one foundation in England, The Royal Institution (founded in 1800 ), where science was systematically expounded and scientific research officially conducted. In the departments related to medicine especially, England was behind the times.

There was a notable inferiority of the anatomical instruction in London as compared to that in Paris. In Paris, moreover, was the great Muséum d'Histoire Naturelle where the principles of comparative anatomy had been founded by Lamarck (1744-1829), Cuvier (1769-1832), and Etienne Geoffroy St. Hilaire (I 772-1844). The width, depth and philosophic insight of Augustin Pyrma dee Condolle (I 778-184I) in his investigation of plants made him a worthy colleague of these men. There was nothing in London to compare to these efforts. We go through nearly all the sciences and find the same discrepancy.

The French Revolution had involved also a revolution in the system of medical education which may be dated from the opening of l'Ecole de Santé in Paris in I 794. In French eyes, at least, its most typical reformer was M. F. X. Bichat (177I-1802). His influence on medicine is summed up in his own aphorism, 'A few autopsies yield more light than twenty years of observation of symptoms'. This influential but very short-lived teacher, by stressing tissues rather than organs, by discussing, for example, pericarditis, myocarditis, and endocarditis, rather than inflammation of the heart, laid the foundation for a new study of morbid anatomy. His true heirs were Cruveilhier (1791-1858) in Paris, and Robert Carswell (1 793-1857) in London. As for clinical research, J. N. Corvisart (I755-182I), Napoleon's chosen medical attendant, drew attention to the value of percussion by his teaching and by his translation in I808 from the Latin of the Inventum Novum (I 76r) of Auenbrugger (I 722-1809). Above all R. T. H. Laennec ( $178 \mathrm{I}-1826)$, Corvisart's pupil, in another brief life, raised physical signs to a scientific level by his invention and use of the stethoscope and by his clinical and pathological descriptions of pulmonary disease (1819). After naming these great Parisian figures, which could be multiplied by ten, it seems unnecessary to enumerate also the great contemporary exponents of medicine as a science in the German-speaking countries where the achromatic microscope became and remained for a century the great instrument 


\section{Early Medical Education in England}

of biological research. The fact is that, despite the tradition of the Hunters and despite a series of admirable clinical observers, notably Matthew Baillie (176r-1823), Thomas Bright (1781-1858), Thomas Addison ( $1783-1860)$ and Thomas Hodgkin ( $1783-1860)$, London in the first decades of the century had none who could influence medical thought broadly and deeply. True, she had a series of brilliant operators but these added little to medical science. The realization of the scientific inferiority of England, and specifically of London, to Paris and to many other continental centres, was a factor in the movement that led to the foundation of London University. 